\title{
Radiocarbon
}

1965

\section{BERN RADIOCARBON DATES IV}

\author{
H. OESCHGER and T. RIESEN
}

Physikalisches Institut, Universität Bern

This list covers part of the samples measured at the Radiocarbon Dating Lahoratory, Physics Department, University of Bern since summer 1962. Two low-level counters, as described by Houtermans and Oeschger (1958), with incorporated anticoincidence are used. Each sample is measured in both countrs. The $\mathrm{CO}$. from the sample is converted to methane by pumping a $\left.(\mathrm{CO})_{2}+\mathrm{H}_{2}\right)$-mixture at a pressure below $1 \mathrm{~atm}$ over a Ru-catalyst at $200^{\circ} \mathrm{C}$.

A difficulty consists in a higher background due to $\mathrm{H}^{3}$ in the $\mathrm{H}_{2}$ commercially available. The lowest background was obtained with hydrogen from "Knappsack-Griesheim AG. Düsseldorf, Germany." Table 1 shows backgrounds ohtained with different counting gases.

\begin{tabular}{|c|c|c|}
\hline Counting Gas & Pressure & Background \\
\hline $\mathrm{C}_{2} \mathrm{H}_{4}$, fossil from Gerling-Holz \& Co., Hanau, Germany & $700 \mathrm{~mm} \mathrm{Hg}$ & $0.9 \mathrm{cpm}$ \\
\hline Methane, $\mathrm{H}_{2}$ from tapwater electrolysis (Carba AG. Bern) & $1200 \mathrm{~mm} \mathrm{Hg}$ & $2.0 \mathrm{cmm}$ \\
\hline $\begin{array}{l}\text { Methane, } H_{2} \text { from Knappsack-Griesheim, Dusseldo:t, } \\
\text { Germany }\end{array}$ & $1200 \mathrm{~mm} \mathrm{H}$ & $1.0 \mathrm{cpm}$ \\
\hline
\end{tabular}

For dating extremely small samples (15 to $50 \mathrm{mg}$ carbon) a special counter based on the principle of the others but with separate volume was constructed. The thickness of the separating foil is $19 \mathrm{mg} / \mathrm{cm}^{2}$, the volume of the inner counter $40 \mathrm{~cm}^{3}$. A lackground of $0.17 \mathrm{cpm}$, only slightly dependent on pressure, was obtained. Probably hecause of contamination of the foil, the hackground now is $0.23 \mathrm{cpm}$. Table II shows a comparison of measurements of identical samples with the usual counter (1.5 L sensitive volume) and with the small counter (Loosli, 1963; Ocschger, 1963).

\begin{tabular}{|c|c|c|c|c|}
\hline Sample & $\begin{array}{l}\text { Pressure in } \\
\text { sinall counte. }\end{array}$ & $\begin{array}{c}\text { Amount of } \\
\text { Carbon }\end{array}$ & $\begin{array}{l}\text { age } \\
\text { small counter }\end{array}$ & $\begin{array}{c}\text { age } \\
1.5 \mathrm{~L} \text { counter }\end{array}$ \\
\hline B-450 & $415 \mathrm{~mm} \mathrm{Hg}$ & $12 \mathrm{mg}$ & $300 \pm 900 y$ & $930 \pm 100 y$ \\
\hline B-397 & $760 \mathrm{~mm} \mathrm{Hg}$ & $21 \mathrm{mg}$ & $1560 \pm 640 y$ & $1460 \pm 100 y$ \\
\hline B-369 & $675 \mathrm{~mm} \mathrm{Hg}$ & $19 \mathrm{mg}$ & $6300 \pm 900 y$ & $5500 \pm 120 y$ \\
\hline B. 439 & $780 \mathrm{~mm} \mathrm{Hg}$ & $22 \mathrm{mg}$ & $9000 \pm 1100 y$ & $10,580 \pm 120 y$ \\
\hline
\end{tabular}


A grid wall counter $(1.5 \mathrm{~L})$ with a background in our laboratory of 0.55 cpm was transported with its shield into a tunnel below $20 \mathrm{~m}$ of rock. A background of $0.36 \mathrm{cpm}$ was measured. The reduction is supposed to be mainly due to the lower $\mu$-meson flux.

This work was financed by the Schweizerischer Nationalfonds. The authors wish to thank H. Loosli and B. Stauffer for their assistance in the measurement of part of the samples. They also thank Max Welten and H.-G. Bandi for their help in selecting and discussing the samples.

\section{SAMPLE DESCRIPTIONS}

\section{B-358. Moosbühl near Bern}

$$
\begin{gathered}
10,300 \pm 180 \\
8350 \text { в.с. }
\end{gathered}
$$

Charcoal sample mixed with sand from a late Magdalenien camp site at Moosbühl $\left(47^{\circ} 00^{\prime} 75^{\prime \prime} \mathrm{N}\right.$ Lat, $7^{\circ} 29^{\prime} 50^{\prime \prime} \mathrm{E}$ Long). Coll. 1960 by H. Schwab and subm. by H.-G. Bandi, Univ. of Bern. Comment (H.S.) : date in second half of 9 th millenium B.c. is possible although perhaps a little too young.

\section{Wallbach-Lenk series, Simmental, Switzerland}

Peat from a small bog, $250 \mathrm{~cm}$ deep, near recent timber line, on Bernese Oberland, W of Lenk ( $46^{\circ} 27.7^{\prime} \mathrm{N}$ Lat, $7^{\circ} 24.9^{\prime} \mathrm{E}$ Long $)$. Moss and sedge peat taken by cutting to $155 \mathrm{~cm}$ depth, deeper by Hiller borer. Section is particularly useful for its clear postglacial pollen diagram. Coll. Aug. 1961 and subm. by Chr. Gfeller and M. Welten, Univ. of Bern. Comment (M.W.) : a very consistent series dating a clear pollen diagram with different oscillations and interesting changes of growth rate.

B-364. Wallbach-Lenk, $8 \mathrm{~cm}$ depth

B-365. Wallbach-Lenk, $30 \mathrm{~cm}$ depth

B-366. Wallbach-Lenk, $60 \mathrm{~cm}$ depth

B-367. Wallbach-Lenk, $100 \mathrm{~cm}$ depth

B-368. Wallbach-Lenk, $130 \mathrm{~cm}$ depth

B-369. Wallbach-Lenk, $155 \mathrm{~cm}$ depth

B-370. Wallbach-Lenk, $170 \mathrm{~cm}$ depth

B-371. Wallbach-Lenk, $190 \mathrm{em}$ depth

B-472. Wallbach-Lenk, $207 \mathrm{~cm}$ depth

$$
\begin{aligned}
& 130 \pm 100 \\
& \text { A.D. } 1820 \\
& 930 \pm 100 \\
& \text { A.D. } 1020 \\
& 1320 \pm 80 \\
& \text { A.D. } 630 \\
& 1660 \pm 100 \\
& \text { A.D. } 290 \\
& 4380 \pm 120 \\
& 2430 \text { в.c. } \\
& 5500 \pm 120 \\
& 3550 \text { в.с. } \\
& 6410 \pm 150 \\
& 4460 \text { в.c. } \\
& 6820 \pm 150 \\
& 4870 \text { в.c. } \\
& 7360 \pm 160 \\
& 5410 \text { в.c. }
\end{aligned}
$$




\section{B-373. Wallbach-Lenk, $221 \mathrm{~cm}$ depth}

$8000 \pm 120$

6050 в.c.

\section{Petsikko series, Inari, Finland}

Peat from palsa bog near Petsikko fjeld, Finnish Lapland $\left(69^{\circ} 28^{\prime} \mathrm{N}\right.$ Lat, $27^{\circ} 20^{\prime}$ E Long). Coll. 1961 and 1962 by Rauno Ruuhijärvi, Dept. of Botany, Univ. of Helsinki, Finland. Series taken with piston drill specially constructed for $\mathrm{C}^{14}$ samples. Comment (R.R.) : series gives dates of the history of forests and peatlands in Finnish Lapland. Comparison of profiles in frozen palsa (2.2 $m$ in height) and an unfrozen hollow was intended to give information on formation and age of permafrost.
B-415. Palsa, I, $50 \mathrm{~cm}$ depth
$3120 \pm 120$
1170 в.c.

Sphagnum peat from hand-dug section. According to pollen analysis, horizon is from beginning of younger Betula-period.

\section{B-416. Palsa I, 200-215 cm depth}

$8020 \pm 160$

6070 в.C.

Frozen Carex-Bryales peat from hand-dug section in palsa, from upper part of older Betula-period.

\section{B-417. Palsa I}

$8030 \pm 150$

6080 в.C. palsa.

Same pollen horizon as in B-416, but in unfrozen hollow peat under the

\section{B-418. Hollow, 32-38 cm depth}

$4800 \pm 120$

Carex-peat fro mend of Pinus-period.

\section{B-419. Hollow, 65-75 cm depth}

Carex-Bryales peat from Atlantic Pinus-period.

B-420. Hollow, 110-117 cm depth

2850 в.c.

Carex-Bryales peat from end of older Betula-period.

B-421. Hollow, 190-200 cm depth

Carex-Bryales peat from middle of older Betula-period.

\section{B-422. Hollow, 250-255 cm depth}

$6570 \pm 120$

4620 в.c.

$7890 \pm 160$

5940 в.с.

$8950 \pm 200$

7000 в.с.

Bryales peat from bottom of profle. Com with B-510 and B-421.

\section{B-509. Palsa I, 415-420 em depth}

$8550 \pm 300$

Unfrozen Bryales-Carex peat under the frozen palsa; almost the same pollen horizon as in B-421.

\section{B-510. Palsa I, 470-475 cm depth}

$9800 \pm 250$

Bryales-peat from bottom of profile. 


\section{B-511. Palsa II, 50-51 cm depth}

Sphagnum peat from another palsa $(4.5 \mathrm{~m}$ in height) taken from handdug section; beginning of younger Betula-period according to pollen analysis. Almost the same pollen horizon as in B-415.

\section{Mizque series, Bolivia}

Charcoal (wood) from Mizque, Bolivia ( $18^{\circ} 55^{\prime} \mathrm{S}$ Lat, $65^{\circ} 20^{\prime} \mathrm{W}$ Long). Coll. and subm. by H. Müller-Beck. Comment (H.M.-B.) : samples have been taken in a systematic excavation of the German Archaeol. Survey in Bolivia. 1960 (Head: H. Trimborn, Bonn) with reliable stratigraphic control. The dates $1110 \pm 100$ and $1020 \pm 100$ are connected with local ceramic styles older and deeper than the first irue Tiahuanaco-ware in the whole area; $930 \pm 100$ and $840 \pm 100$ date levels from the same trench, which are connected with well-made Tiahuanaco-style ware (late classic or "expansivo"). The two last dates are in direct and proper stratigraphic sequence.

\section{B-446. Mizque 1}

$1110 \pm 100$

Trench CK-2, 120 to $130 \mathrm{~cm}$ depth. with local ware in Pre-Tiahuanacostyles.

B-448. Mizque 2

$1020 \pm 100$ A.D. 930

Trench GK, 50 to $80 \mathrm{~cm}$ depth, with local ware in Pre-Tiahuanaco-style.

\section{B-449. Mizque 3}

$840 \pm 100$ A.D. 1110

Trench RB, 60 to $80 \mathrm{~cm}$ depth. with late Tiahuanaco-classico or "expansivo"; style already in a high percentage "weak."

\section{B-550. Mizque 4}

\section{A.D. 1020}

$930 \pm 100$

Trench RB, 140 to $160 \mathrm{~cm}$ depth, with late Tiahuanaco classico or "expansivo"; style goo!.

\section{Lobsigensee series, Switzerland}

Dy (B-398) and gyttja taken by boring with Hiller-sampler near lakeward edge of Phragmites girdle on $\mathrm{N}$ shore. Lake is in the Bernese Seeland near Aarberg $\left(47^{\circ} 1^{\prime} 56^{\prime \prime} \mathrm{N}\right.$ Lat, $7^{\circ} 17^{\prime} 57^{\prime \prime} \mathrm{E}$ Long, alt $\left.514 \mathrm{~m}\right)$. Coll. Nov. 9. 1961 (B-453, Oct. 8, 1962 ) by R. Häni, K. Ammann and M. Welten; subm. by M. Welten. Comment (M.W.) : samples date a 10 -m profile covering entire late- and postglacial vegetation development.

\section{B-453. Lobsigensee, $302 \mathrm{~cm}$ depth}

$1960 \pm 120$

10 B.C. ly dated.

Roman invasion of 58 B.C., also inferred palynologically, seems very exact.

\section{B-452. Lobsigensee, $452 \mathrm{~cm}$ depth}

$4880 \pm 100$

Carpinus invading; Fagus had been present for ca. 100 yr. 


\section{B-398. Lobsigensee, $858 \mathrm{~cm}$ depth}

Late-glacial hirch-physe. Sample seems the first of Bölling age in Switzerland. Further investigations are necessary.

\section{B-457. Neubriigg, near Bern, Switzerland}

During construction of sewage disposal plant at Neuhrügg near Bern $\left(46^{\circ}\right.$ $58^{\prime} 22^{\prime \prime} \mathrm{N}$ Lat, $7^{\circ} 25^{\prime} 52^{\prime \prime} \mathrm{E}$ Long), small piece of wood was found in sandy layers underlying "Karlsruhe"-gravels believed to be of late Riss age. Coll. and subm. by W. Nabholz, Univ. of Bern. Comment: sample confirms pre-Würm-II age of sands and gravels and corresponds well with palynological results.

\section{B-471. Afyeh, Nubia, Egypt}

$4500 \pm 120$

2550 в.c.

Charcoal from habitation site of Nubia, Egypt $\left(22^{\circ} 30^{\prime} \mathrm{N}\right.$ Lat, $31^{\circ} 50^{\prime} \mathrm{E}$ Long). Coll. 1962 and subm. hy B. B. Lal, Director, School of Archaeol., New Delhi, India. Comment (B.L.) : sample from habitation site of A-Croup people of Nubia, dated according to current Egyptian chronology at ca. 3000 B.C.

\section{Alp Frisal series, Graubiinden, Switzerland \\ B-473a. Alp Frisal bei Breil \\ $8530 \pm 150$ \\ 6580 B.C.}

Wood from technical boring in valley floor at depth of $23.8 \mathrm{~m}$, determined as Pinus (probably cembra). Lefthand side of the Vorderrheintal $\left(46^{\circ} 48.5^{\prime}\right.$ N Lat, $9^{\circ} 1.6^{\prime} \mathrm{E}$ Long, alt $1879 \mathrm{~m}$ ). Coll. 1962 by W. Flück; subm. by J. Cadisch, Univ. of Bern. Comment (M.W.) : indicates early postglacial filling of the valley, accompanied by extremely early invasion of Pinus cf. cembra, unexpected at so great an altitude.

\section{B-473b. Alp Frisal bei Breil}

$7380 \pm 150$ 5430 в.c.

Wood (chiefly Pinus cembra) from second technical boring at depth of $33.9 \mathrm{~m}, 34.7 \mathrm{~m}$ and $35 \mathrm{~m}$ (combined), 64 $\mathrm{m}$ from above-mentioned boring. Coll. 1961-62 by W. Flück; subm. by J. Cadisch. Comment (M.W.) : age supports what a series of wood-analyses had made clear: early postglacial alluviation of the valley, probably shortly after melting of glacier and of its dead ice-remnants.

\section{Sugiez series, Switzerland}

During the last 3 yr the canal of the Broye river between the lake of Murten and the lake of Neuchâtel $\left(46^{\circ} 58^{\prime} 00^{\prime \prime} \mathrm{N}\right.$ Lat, $7^{\circ} 06^{\prime} 45^{\prime \prime} \mathrm{E}$ Long $)$ was enlarged and lowered. During construction archaeological remains were located at different spots. Coll. 1963 by H. Schwab; subm. by H.-G. Bandi, Univ. of Bern. Comment (H.S.) : some remains could be dated archaeologically but the age of most of them was uncertain. Therefore the $\mathrm{C}^{14}$ dates are of particular importance in determining when the region was marshy and when it was dry enough to be settled. 


\section{B-483. Pré Vagnard/Sugiez}

Charcoal directly underlying traces of roman occupation. Comment: the fact that the layer in question is of Neolithic age makes it probable that the area was more or less dry from the Neolithic to the Roman period. Surface of Neolithic layer is about $50 \mathrm{~cm}$ below average water level of today.

\section{B484. Old course of the Aare-river/Sugiez $\quad 3180 \pm 130$ \\ 1230 в.с.}

Wooden sample dating Bronze Age sword of Rixheim type (ca. 1250 B.c.).

\section{B-486. Lake of Murten near Sugiez}

$2640 \pm 130$ 690 B.C.

Worked vertical wooden pole, alt $427.25 \mathrm{~m}$ above sealevel. Comment: the date and the fact that several older Iron Age sites are known at the identical altitude from the lake of Neuchâtel make it probable that the pole was placed during the older Iron Age.

\section{B-477. Pré Vagnard/Sugiez}

$1470 \pm 100$

B-481. Pré Vagnard/Sugiez A.D. 480

\section{B-480. Pré Vagnard/Sugiez}

$1310 \pm 100$ A.D. 640

A.D. 970

$980 \pm 100$

Comment: dates of 3 samples from vertical wooden poles show that area was also settled after Roman period.

\section{B-478. Old course of the Broye river near Sugiez \\ $1190 \pm 100$ \\ B-479. Old course of the Broye river near Sugiez
$1690+100$ A.D. 260

Comment: dates of 2 peat samples of an old course of the Broye river. completely covered today, make it prohable that this stream began to diminish in the period from the 3 rd to the 8th century A.D.
B-485. Tour de Chène/Sugiez
$670 \pm 100$ A.D. 1280

Wooden sample from foundation of a medieval tower. Comment: confirms that building was erected during 13 th century A.D.

\section{B-487. Lewisville, Texas}

Charcoal from Lewisville Dam locality, Texas, L. S. A. $\left(33^{\circ} 04^{\prime} 00^{\prime \prime} \mathrm{N}\right.$ Lat, 96 59' 30" W Long). Coll. before 1957 by W. W. Crook and R. R. Harris; subm. by H. Müller-Beck as check on 0-235 and 0-248 (>37.000; Humble I) and UCLA-110 (>38.000; UCLA I). Comment (H.M.-B.) : charcoal dates faunal remains from the Upper Shuler formation as older than 40,000 B.P., but does not necessarily date also the few artifacts found. It is 
more likely that the numerous "hearths" which have been excavated (Crook and Harris, 1957, 1958), are traces of a prairie-fire, synchronous with the PreWisconsin fauna. The artifacts found without doubt in situ within a few inches beneath the mechanically exposed surface of the Upper Shuler formation could have been lost and deposited on top of an unobserved secondary erosion-surface. There are no known stratigraphic data from the removed overburden near the artifact deposit. For this reason, until better evidence is available, those artifacts should be considered as intrusive in a geological sense and younger than faunistic remains, fire, and dates.

\section{Tiwanaku, Kalasasaya series, Bolivia}

Charcoal (wood) and ash from Tiwanaku, Kalasasaya $\left(16^{\circ} 30^{\prime} \mathrm{S}\right.$ Lat, $68^{\circ} 40^{\prime} \mathrm{W}$ Long). Coll. Nov and Dec 1957 by C. Ponce Sanginés (Centro de Inv. Arqueol. en Tiwanaku) ; subm. by H. Müller-Beck. Comment (H.M.-B.) : samples date levels with ware older than classical Tiahuanaco. All dates are in proper stratigraphic sequence, even B-488 and B-489, which are only $15 \mathrm{~cm}$ apart. The dates 2500 to 2400 B.P. seem probable for the material of the socalled Epoch 1 of the site, likewise 2100 B.P. for Epoch II. This would be the same range as the Paracas style in Peru (P-516: $2408 \pm 214$, Pennsylvania VI; Wallace, 1962). Other dates for Epoch I : $1653 \pm 61$, P-532, Pennsylvania VI (seems too young, as shown by P-534 for Epoch II); $1990 \pm 110$, GaK192. Gakushuin II; $1850 \pm 90$, GaK-193, Gakushuin II; $3530 \pm 120$, GaK194, Gakushuin II (noted in the original comment as "unexpectedly old"). Dates for Epoch II: $1866 \pm 62$, P-534, Pennsylvania VI; $1750 \pm 100$, GaK195, Gakushuin II. The dates GaK-52, $2190 \pm 130$, from layer 6, and GaK-53, $2410 \pm 140$, from layer 4, Square F-15, (Gakushuin 1) are for samples whose archaeological relations are unpublished.

\section{B-488. Tiwanaku 4-1957}

$$
\begin{gathered}
2400 \pm 200 \\
450 \text { в.c. }
\end{gathered}
$$

Square F-14, layer 6, level 7 (-255 cm); Archaeological Epoch I.

\section{B-489. Tiwanaku 5-1957}

Square E-14, layer 6, level $7(-270 \mathrm{~cm})$; Archaeological Epoch I.

\section{B-490. Tiwanaku 6-1957}

Square F-15, layer 4, level 6; Archaeological Epoch II.

\section{B-514. Mattmark, Wallis, Switzerland}

Wood found in a borehole during construction of dam "Mattmark" $\left(46^{\circ}\right.$ $03^{\prime} 15^{\prime \prime}$ N Lat, $7^{\circ} 57^{\prime} 50^{\prime \prime}$ E Long, alt $2044 \mathrm{~m}$ ). Subm. by R. Haefeli, Zurich.

\section{Gänsemoos series, Schwarzenburg, Switzerland}

Peat from bog Gänsemoos, near Schwarzenburg ( $46^{\circ} 50^{\prime} 32^{\prime \prime} \mathrm{N}$ Lat, $7^{\circ}$ $21^{\prime} 24^{\prime \prime}$ E Long). Coll. 1962 and subm. by Max Welten. Comment (M.W.) : the three dates (from above downward) fix the establishment of beech-woods, the appearance of white spruce (Abies alba) and the beginning of the postglacial 
hazel-phase, respectively, on the tiny and seldom ice-covered plateau of Schwarzenburg between the ancient ice-streams of the Aare and Rhone glaciers. Further investigation of these partly ice-free highlands $\mathrm{N}$ of the Alps has begun.

\section{B-526. Gänsemoos, $187 \mathrm{~cm}$ depth}

\section{B-527. Gänsemoos, $335 \mathrm{~cm}$ depth}

\section{B-528. Gänsemoos, $487 \mathrm{~cm}$ depth}

$5570 \pm 100$ 3620 в.с.

$7220 \pm 120$ 5270 в.с.

$9830 \pm 150$

\section{Creux du Croue series, western Jura, Switzerland}

Sphagnum peat from bog at Creux du Croue, near Le Noirmont, in western Jura $\left(46^{\circ} 29^{\prime} 48^{\prime \prime} \mathrm{N}\right.$ Lat, $6^{\circ} 7^{\prime} 17^{\prime \prime} \mathrm{E}$ Long, alt $\left.1360 \mathrm{~m}\right)$. Coll. 1958 by Samuel Wegmüller; subm. by Max Welten. Comment (S.W.) : considering the altitude of the bog, the profile shows an extraordinarily favorable development of the postglacial vegetation. In the same bog, B-330 (8430 \pm 120 ; Bern III) dates the phase of Corylus in southwestern Jura for the first time; B-551 dates beginning of the Abies-phase; B-331 (4350 \pm 100; Bern III) the phase of Picea; and B-550 falls in a long dominance of Picea-Ahies.

\section{B-550. Creux du Croue, $60 \mathrm{~cm}$ depth}

\section{B-551. Creux du Croue, $260 \mathrm{~cm}$ depth}

\section{B-549. Lac de Narlay, western Jura, France}

$$
\begin{aligned}
& 1890 \pm 100 \\
& \text { A.D. } 60 \\
& \mathbf{5 7 5 0} \pm \mathbf{2 0 0} \\
& \mathbf{3 8 0 0} \text { в.C. } \\
& \mathbf{3 5 5 0} \pm \mathbf{2 0 0} \\
& \mathbf{1 6 0 0} \text { B.C. }
\end{aligned}
$$

Gyttja of chalk from Lac de Narlay, western Jura, France $\left(46^{\circ} 38^{\prime}\right.$ N Lat, $5^{\circ} 54^{\prime}$ E Long, alt $\left.748 \mathrm{~m}\right)$. Coll. by S. Wegmüller; subm. by M. Welten. Comment (S.W.) : B-549,between B-285, $4120 \pm 100$ and B-286. $1050 \pm 80$ (Bern II), dates a phase of settlement in the Bronze Age. Between B-549 and B-286 was an interruption of the growth of this deposition.

Date lists:

REFERENCHS

$\begin{array}{ll}\text { Bern II } & \text { Gfeller, Oeschger and Schwarz, 1961 } \\ \text { Bern III } & \text { Gfeller and Oeschger, 1963 } \\ \text { Gakushuin I } & \text { Kigoshi, Tomikura and Endo. 1962 } \\ \text { Gakushuin II } & \text { Kigoshi, Tomikura and Endo, 1963 } \\ \text { Humble I } & \begin{array}{l}\text { Brannon and others, 1957 } \\ \text { Pennsylvania VI }\end{array} \\ \text { Stuckenrath, 1963 } \\ \text { ECLA I } & \text { Fergusion and Libby, 1962 }\end{array}$

Brannon, H. R., Daughtry, A. C., Perry, D., Simons, L. H., Wyitaker, W. W., Williams, M., 1957, Humble Oil Company radiocarbon dates I: Science, v 125, p. 147-150.

Crook, W. W., and Harris, R. K., 1957, Hearts and artifacts of early man near Lewisville, Texas, and associated faunal material: Bull. Texas Archaeol. Soc., v. 28, p. 7-97.

Fergusson, G. J., and Libby. II. F., 1962. University of California. Los Angeles, natural radiocarbon measurements I: Radiocarbon, v. 4, p. 109-114.

Gfeller, Chr., Oeschger, H., Schwarz, U., 1961, Bern radiocarbon dates II: Radiocarbon, v. 3 , p. $15-25$.

Gfeller, Chr., Oeschger, H., 1963, Bern radiocarbon dates III: Radiocarbon, v. 5, p. 305-311. 
Houtermans, F. G., and Oeschger, H., 1958, Proportionalzählrohr zur Messung schwacher Aktivitäten weicher $\beta$-Strahlung: Helv. Phy. Acta, v. 31, p. 117-126.

Kigoshi, Kunihiko, Tomikura, Yoshio and Endo, Kunihiko, 1962, Gakushuin natural radiocarbon measurements I: Radiocarbon, v. 4, p. 84-94.

Kigoshi, Kunihiko and Endo, Kunihoko, 1963, Gakushuin natural radiocarbon measurements II: Radiocarbon, v. 5, p. 109-117.

Loosli, H. H., 1963, Zählrohr für C ${ }^{14}$-Altersbestimmungen an kleinen Proben: Physikalisches Inst. der Univ. Bern, thesis.

Oeschger, H., 1963, Low-Level Counting Methods: Radioactive Dating, IAEA, Vienna, p. 13-34.

Stuckenrath, R., 1963, Univ. of Pennsylvania radiocarbon dates VI: Radiocarbon, v. 5, p. $82-103$.

Wegmueller, S., 1965, Beitrãge zur geobotanischen Landesaufnahme: Botanisches Inst. der Univ. Bern, in press. 